Mr. Letts has occupied the office for five years and has made valuable contributions to the publications of the Society. The honorary secretary of the Society is Mr. R. A. Skelton, superintendent of the Map Room of the British Museum (London, W.C.1), who has done much in helping with the publication of the Cook volumes.

\section{Physics and Philosophy}

The first Robert Grosseteste Memorial Lecture, given by Lord Cherwell on May 21 last, was delivered most appropriately in the Chapter House of Lincoln Cathedral; it has now been published (pp. 21. London: Oxford University Press, 1955; 2s. 6d. net). In it Lord Cherwell performs a valuable service in pleading for a closer understanding between physics and philosophy such as, in broad outline, existed in the lifetime of the great bishop and scholar in whose honour he was speaking. An excep. tionally clear picture is presented of the æsthetic choice before the investigator in modern physics, coupled with the recognition that an axiological olement is not excluded, thus revealing a measure of personal preference. It is one of the major tragedies of modern thought that the natural philosopher of to-day is expected to know all the answers, whereas, in fact, he is taking a quite limited sector of awareness as his plane of discourse-and likewise for workers in other fields of knowledge. The well-known antipathy of metaphysicians towards mathematics, and the reluctance of physicists to meditate upon fundamentals, are symptoms of a somewhat arid intellectual climate in which the triumphs of science have been won, but which is not necessarily conducive to "helping bewildered humanity to confront the mysteries of existence".

\section{Green Earthworms}

The eastern United States has boen invaded by a plague of green earthworms (Smithsonian Institution News Release, Dec. 9, 1955). In a few areas these immigrants from China and Manchuria have become a serious problem for keepers of golf courses because of their borings in putting greens. In a night they may cover a best-kept green with little piles of earth. This particular earthworm, Pheretima hupeiensis, was first described more than fifty years ago from the Hupei Province of China, and its first appearance in the United States, near Philadelphia, was noted in 1933. Since then there have been numerous reports from golf clubs which almost unquestionably deal with the same species. Presumably it was introduced into America on some kind of nursery stock from China and has been spread by transportation of turfs from one golf course to another. It is such a serious problem in Westchester County, N.Y., and southern Connecticut that the Connecticut Agricultural Experiment Station has instituted a control programme. It is a slender worm, 1-3 in. long. Its colour varies from pale green to deep olive. A distinct purple or black line is apparent on the back.

\section{The Cross-Bill}

ONE of the excellent leaflets issued by the Forestry Commission deals with the cross-bill, Loxia curvirostra (Leaflet No. 36 ; pp. 11. London: H.M.S.O., 1955 ; $9 d$. net). Besides an illustrated description of the bird, accounts are given of its habitat, song, behaviour, feeding habits and distribution in Great Britain. For the forester the important section is one describing its economic significance. Although the cross-bill does not breed anywhere in Great Britain in numbers large enough to cause the slightest alarm to foresters, it cannot be described as a 'beneficial' bird ; it takes some insects and some of them may be harmful to sylviculture, though the amount involved is too small to be of economic account. The leaflet recommends that, for the present, it is best to regard the crossbill as a highly specialized inhabitant of mature coniferous woodland the ordinary life-history and feeding habits of which are by no means well known, and which-in respect of the periodic invasionsposes a problem of great biological interest still awaiting solution.

\section{Gold Coast Pteridophyta}

A comprenensive list of the Pteridophyta in the Gold Coast has recently been prepared by C. D. Adams and A. H. G. Alston (Bull. Brit. Mus. (Nat. Hist.) Bot., 1, 6, 143; 1955). This is an up-to-date statement of the taxonomy, nomenclature and broad distribution of most of the indigenous species, and includes habitat notes based on extensive field observations in the Gold Coast and neighbouring territories and on collectors' annotations. The classification used for the ferns is that of R. E. Holttum (1947). The Pteridophyta are poorly repre. sented in the savannah country and include only such plants as show a geophytic habit or are aquatic annuals. Endemic species are stated as being almost totally absent. Pteridophytes other than the ferns are represented by a relatively small number of species.

\section{Films in Human Relations}

The industrial committee of the Scientific Film Association organized a conference at Ashorne Hill during May 24-26, 1955, on the use of the film in the improvement of human relations in industry, and the report of the proceedings (pp. 24 ; from the Association; $2 s .6 d$.) shows the need for more readily accessible information about available films that are suitable for education and training in industry. A new and comprehensive catalogue of all industrial films available in Great Britain is both desirable and necessary. Such a publication would not be an end in itself. 'l'o be of lasting use it would have to be supplemented by an information service which could keep catalogued information up to date and answer specific inquiries about industrial films. The Scientific Film Association is anxious to provide such a servico, which can, how. ever, only be established when sufficient funds are available. To gather information in this way is an important step which must be taken before further serious investigation can be made into the use and efficacy of films in industry.

\section{Indian Society of Genetics and Plant Breeding}

THE sixteenth annual general meeting of the Indian Society of Genetics and Plant Breeding was held at New Delhi on December 12 under the presidentship of Dr. T. R. Mehta, joint director of research, Madhya Bharat College of Agriculture and Research Institute, Gwalior, who delivered an address on "The Genotype in Agriculture". At the meeting it was decided to organize a symposium, to be held later in the year, on the role of genetics in the improvement of tropical crop plants. The following were elected officers of the Society for 1956: President, Prof. V. M. Chavan (Poona); Vice-Presidents, Dr. P. N. Bhaduri (New Delhi) and Dr. G. S. Murty (New 